\title{
Trends in development of architectural and planning solutions for Parish Church Complexes
}

\author{
Maria Ivina $^{1, *}$, Lydia Kondratieva $^{1}$ \\ ${ }^{1}$ State University of Architecture and Civil Engineering, 4, 2 Krasnoarmeiskaya st., St. Petersburg, \\ 190005, Russia
}

\begin{abstract}
The article reveals the most important trends in the development of functional planning and spatial solutions of Christian parish Church complexes. The relevance of the topic is justified by the fact that modern tunneling complexes are not only places of religious practice, but also objects where educational, charitable, leisure and other activities of the parish can be carried out. Thus, a modern temple should be understood as a multifunctional complex, the design of which needs to develop special approaches. It is interesting to study the functional composition, planning structure, architectural and compositional solutions of parish complexes. Currently, the most widespread are multifunctional temple complexes of various directions, the figurative component of which is solved in the methods of innovative architecture. The task of designing them is extremely interesting and is solved in different ways by the professional architectural community.
\end{abstract}

\section{Introduction}

The purpose of this study is to identify current trends in the development of architectural and planning solutions for parish Church complexes (hereinafter referred to as PCC) on the example of foreign and domestic experience.

The analysis of the Russian experience allowed us to determine the features and problems of functional planning and spatial solutions of Orthodox parish Church complexes

The analysis of foreign experience was carried out on the examples of modern PCC of various religious Christian confessions. The architectural and compositional solution and functional content of the complex are of interest, as well as ways of interaction of premises intended for conducting services and organizing communication and multi-faceted interests of modern people.

The study showed that modern PCC are a qualitatively new environment that combines many functions. Various types of daily activities of the population are concentrated in a single architectural ensemble. PCC are a source of spirituality and at the same time a place for believers to spend their time, attracting not only parishioners, but also the population that does not belong to the parish.

\footnotetext{
*Corresponding author: m.s.ivina@mail.ru
} 
The research is based on the works of V. V. Baydin, V. A. Zhemchugova, S. V. Ilvitskaya, and M. V. Ryaguzov, which reveal the problems of designing modern multifunctional Christian complexes. These sources address the issues of formation and stylistic development of modern domestic and foreign religious architecture.

\section{Materials and methods}

The methodological basis of the research is an integrated approach that includes the study of scientific, literary and journalistic sources, statistical data (including Internet sources), design, graphic and photographic materials that characterize the foreign and domestic practice of designing and building modern PCC.

\section{Results}

A review of domestic and foreign experience revealed the architectural and planning features of the PCC organization. [1]

\subsection{Functional and planning solutions}

An important trend is the design and construction of multifunctional PCC that include various functional blocks and zones (table 1).

For example, the St. Martin's temple complex in Hainburg on the Danube (Germany) has a compact space-planning scheme. The functional structure of the complex includes a prayer hall, a universal community hall, the premises of the office of the clergy (office, kitchen, pantry), a hall around which the main premises are formed, and a public garden. A transformable partition is placed between the prayer hall and the community hall, which allows you to increase the space for various events [2].

The complex of the good news in Estoril (Portugal) has an atrium space-planning scheme and includes the following functional areas: worship (temple premises, memorial chapel), administrative (office of the clergy), educational and educational (Sunday and primary schools, kindergarten, day center for the elderly), leisure (gym, auditorium, cafe), economic (Parking, winery, nursery). The various functional areas are connected by multifunctional recreational and communication spaces and are United around a courtyard [3].

For domestic experience, this area is also a priority, but there are not many such facilities built and operating.

As an example, we can mention the large multifunctional spiritual and cultural complex of the Icon of the mother of God "Skoroposlushnitsa" in Slavyanka (St. Petersburg), which includes a Church, Sunday school, Church library, restoration workshops, social refectory and concert hall.

Table 1. Multifunctional composition and division of PCCS into functional blocks and zones.

\begin{tabular}{|c|c|}
\hline Name of object & $\begin{array}{c}\text { Main functional areas } \\
\text { and composition of }\end{array}$ \\
\hline
\end{tabular}




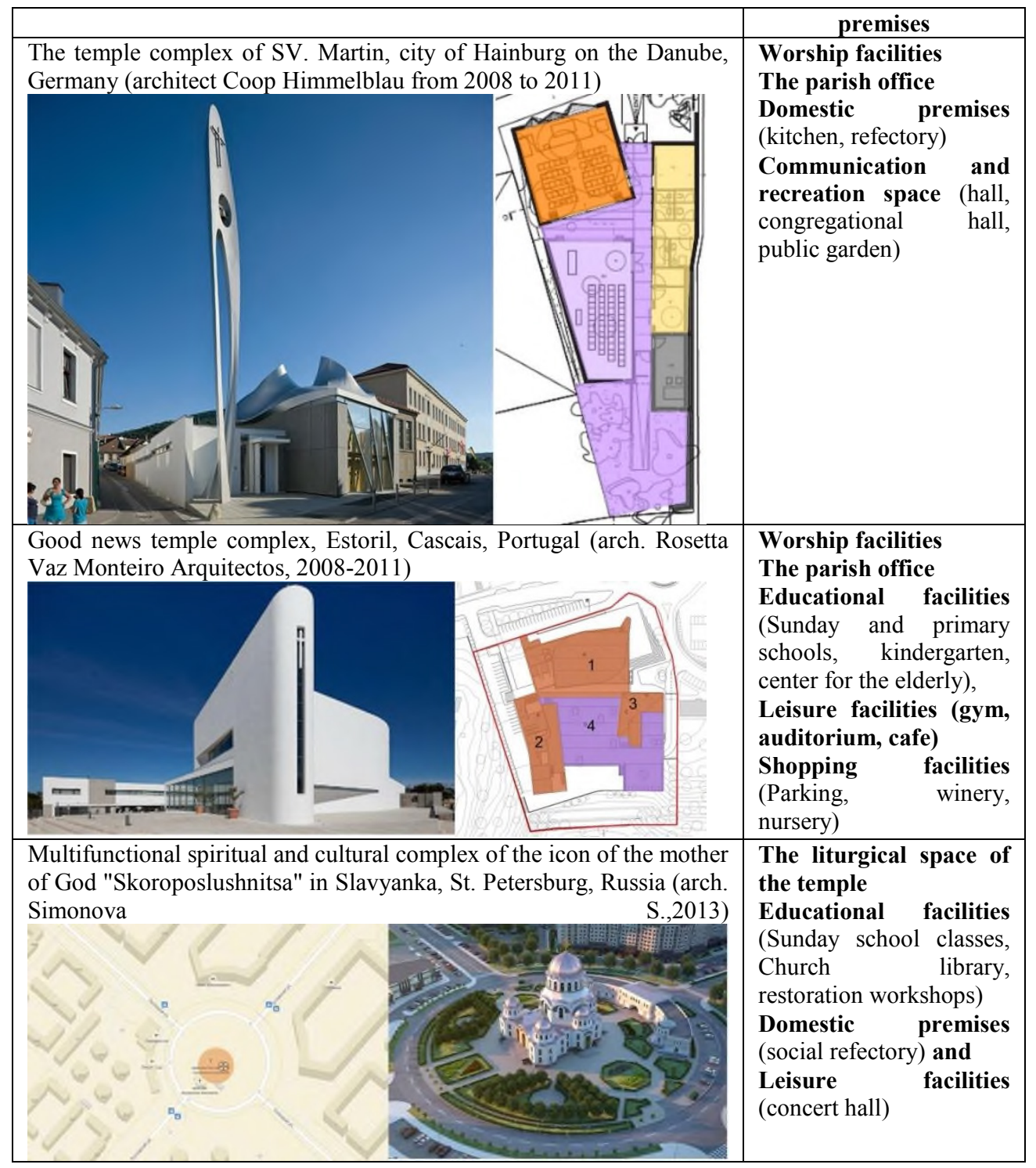

A widespread trend is the creation of specialized PCC dominated by various activities aimed at working with different groups of the population. This is reflected in the functional composition of the PCC.

There are PCC aimed at working with children and young people. These complexes are dominated by the leisure functional zone (table 2).

A striking example is the largest spiritual and educational center in Moscow-the Patriarchal center for spiritual development of children and youth at the Danilov monastery. The complex has a compact spatial planning scheme. The functional structure of the center corresponds to the main activities of the Russian Orthodox Church for the development of children and youth. So, in addition to the liturgical part, the complex includes: concert, discussion and sports halls, a swimming pool, club rooms, a Museum, Sunday school classes, club rooms and a library [4]. 
In St. Petersburg, you can also note the temple complex with a developed leisure functional area - this is a project of the center for spiritual and moral development of youth, which includes the building of the Cathedral in the name of St. Demetrius of Solunsky, the small Church in the name of St. Svetlana and three buildings of the center for spiritual and moral development of youth (swimming pool, gym, pilgrimage hotel, educational facilities).

This area is also a priority for foreign experience.

In the parish Church complex in Scarborough (Canada), in addition to the premises for worship and administrative purposes, there is a sports hall, classrooms, clubs and a multifunctional foyer, which allows you to hold events for children and young people in the parish.

Table 2. Specialized PCC with a dominant leisure function.

\begin{tabular}{|c|c|}
\hline & $\begin{array}{l}\text { Main functional areas and } \\
\text { composition of premises }\end{array}$ \\
\hline $\begin{array}{l}\text { The Patriarchal center of spiritual development of children and } \\
\text { youth, Moscow, Russia (arch. S. D. Posicin, 2004) }\end{array}$ & $\begin{array}{l}\text { Worship facilities } \\
\text { Chapel } \\
\text { Administrative offices of the } \\
\text { parish } \\
\text { Domestic premises (kitchen, } \\
\text { refectory) } \\
\text { Educational facilities } \\
\text { (classrooms, library, clubs) } \\
\text { Leisure facilities (concert, } \\
\text { discussion and sports halls, } \\
\text { swimming pool, Museum) } \\
\text { Domestic and technical } \\
\text { premises (kitchen, bathrooms, } \\
\text { Parking lots) and } \\
\text { Communication space } \\
\text { recreation } \\
\text { (multifunctional foyer, green } \\
\text { roof used) }\end{array}$ \\
\hline $\begin{array}{l}\text { Center for spiritual and moral development of youth, Saint } \\
\text { Petersburg, Russia (arch. Simonova S., project 2010) }\end{array}$ & $\begin{array}{l}\text { Worship facilities } \\
\text { The parish office } \\
\text { Domestic premises (kitchen, } \\
\text { refectory, cafe) } \\
\text { Educational facilities } \\
\text { (Sunday school classes, } \\
\text { library, lecture hall) } \\
\text { Leisure facilities (sports hall, } \\
\text { swimming pool) } \\
\text { Residential premises (hotel } \\
\text { for pilgrims) }\end{array}$ \\
\hline
\end{tabular}




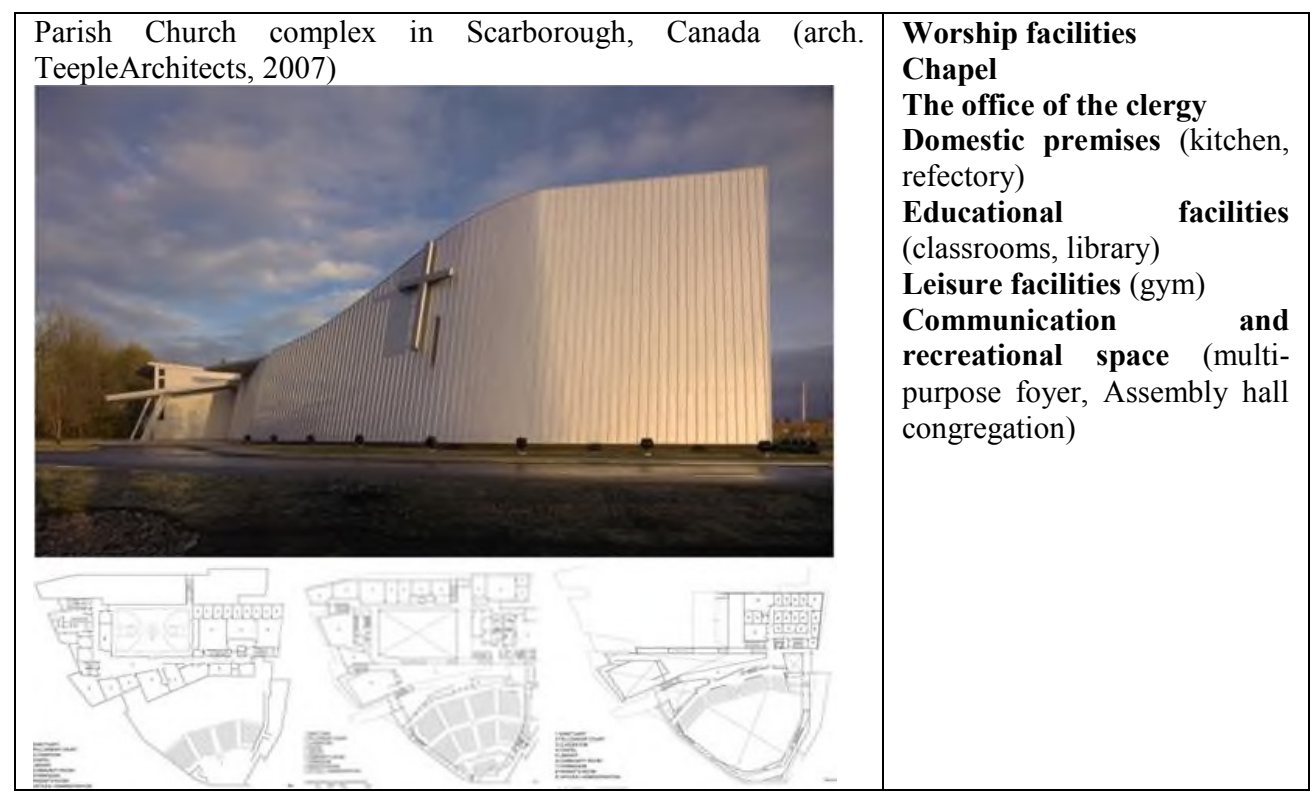

The national experience is characterized by the development of PCC aimed at providing rehabilitation assistance to the population of the "risk" group. These complexes are dominated by medical, residential and economic functions.

Examples include the following: the Orthodox center for medical and social rehabilitation "Ascetic" at the Church of the Holy Apostle Peter and Paul in Polevoy, the rehabilitation center "Sologubovka" at the Church of the Holy Royal passion-Bearers in the village of Sologubovka (table 3).

Table 3. Specialized PCCS with dominating residential and household functions.

\begin{tabular}{|l|l|}
\hline Name of object & \multicolumn{1}{|c|}{$\begin{array}{c}\text { Main functional areas and } \\
\text { composition of premises }\end{array}$} \\
\hline $\begin{array}{l}\text { Orthodox center for medical and social rehabilitation } \\
\text { "Ascetic" Polevskoy (2000) }\end{array}$ & $\begin{array}{l}\text { The liturgical space of the temple } \\
\text { Administrative premises (office of } \\
\text { the Manager, offices of assistant } \\
\text { managers, } \\
\text { caretaker's office) } \\
\text { Residential premises (rehabilitation } \\
\text { rooms) } \\
\text { Educational facilities (classrooms, } \\
\text { library-reading room) }\end{array}$ \\
\hline $\begin{array}{l}\text { Sologubovka rehabilitation center at the Church of the } \\
\text { Holy }\end{array}$ & $\begin{array}{l}\text { The liturgical space of the temple } \\
\text { Residential and domestic premises } \\
\text { (rehabilitation cells, rectory, kitchen, }\end{array}$ \\
\hline
\end{tabular}




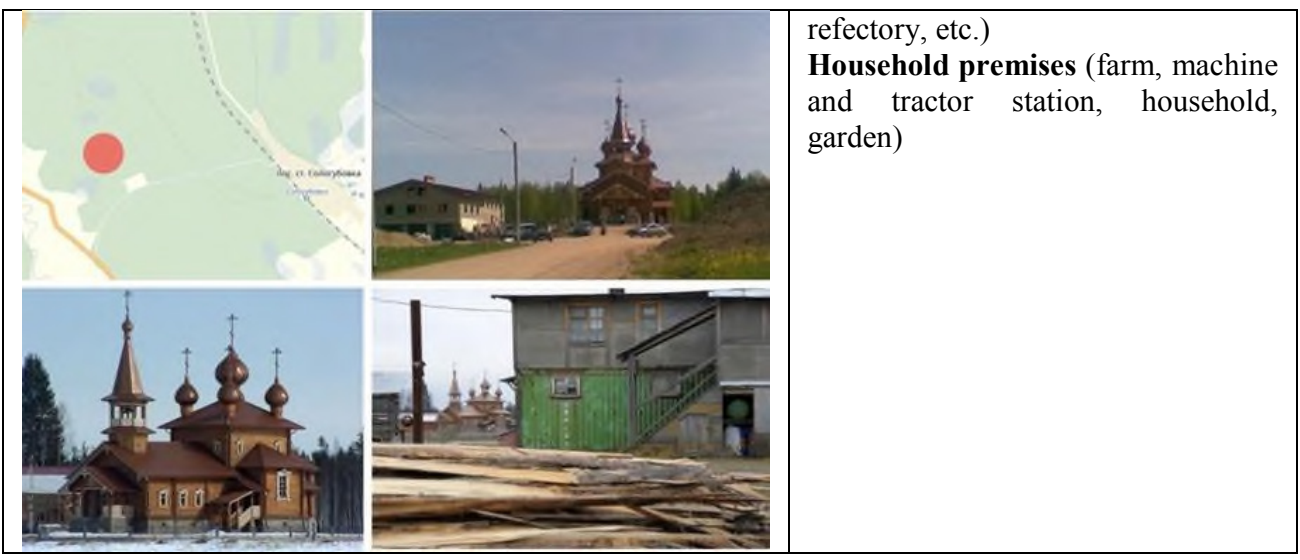

Flexibility of the planning structure of the PCC and universal use of the PCC premises. Creating a functional planning structure that can be transformed is an important trend.

For example, the parish Church in Jyvaskyla Finland has a compact space-planning scheme. The main premises of the complex (Church hall, hall for parish meetings, room for classes with children and youth, hall) they can be combined into a single space or divided into separate zones, which allows you to hold various events with different one-time capacity.

In particular, for foreign experience, it is important to note the presence, in addition to the prayer hall, of a hall for congregations located nearby and functioning both together and separately. This allows you to increase the one-time capacity of the Church during the period of maximum load (holidays, Sunday services). Various events can be held in the congregational hall: worship services, congregations, lectures, holidays, etc. Also, an integral element of the PCC is the courtyard (atrium), which is used in different ways, depending on the characteristics of the rite and climatic conditions [5].

Analysis of domestic experience has shown that, in most cases, temple complexes have a shortage of space, so the premises are used universally. However, as a rule, the parameters and internal equipment of premises do not correspond to the functional processes taking place in them.

\subsection{Three-dimensional solutions}

The use of innovative architectural solutions is an important trend and ensures the creation of a memorable and modern image of the complex.

Foreign architecture is characterized by images of religious buildings that differ from traditional ones. Architects are trying to find the alphabet of a new expressive language that meets the aspirations of the XXI century. New forms have developed due to various reasons, including the development of structures and construction technologies. Nevertheless, in modern churches one can trace the use of associative links and the preservation of traditional Christian symbols. [6-7].

Structural features have a great impact on the appearance of the structure. When creating a unique image of PCC, architects use reinforced concrete shells, hyperbolic paraboloids, hanging coverings, etc.

As examples of buildings with a memorable, modern image, which use traditional Christian symbols, it is interesting to note the following temple complexes: the merciful God the Father in Rome (Italy), the Holy Trinity in Geneva (Switzerland), the Holy Trinity in Hainuwka (Poland), the Holy spirit in Bialystok (Poland) (table 4) [8-9]. 
Table 4. Innovative architectural and compositional solutions.
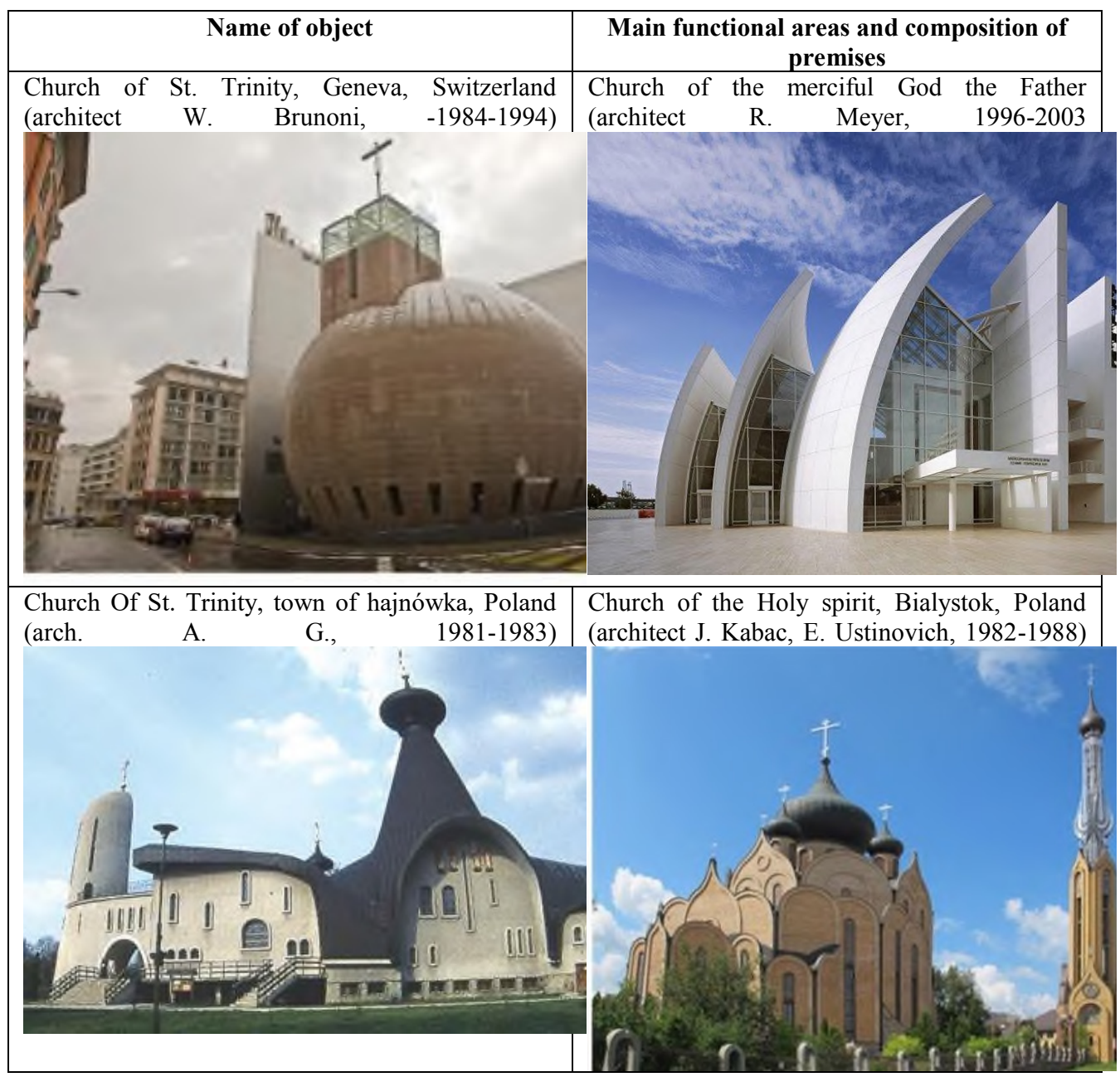

Modern Russian temple architecture is mainly characterized by repeating the styles of past eras or mixing them without reflecting the features of modernity in the appearance of the temple, without considering modern aesthetic, technical and engineering conditions.

A common trend is to combine the Church and functional areas for extra-liturgical purposes into a single complex. This allows you to increase the volume of the temple complex, to ensure dominance in the environment. The compactness of the space-planning solutions of the PCC is due, among other things, to the modern urban development situation (table 5).

A typical example is the largest temple complex of the Holy community in Suwon (South Korea). The complex includes four underground levels where Parking lots, technical rooms, sports and cinema halls, and club rooms are located. On the eight floors of the ground level, there are cafes, a lecture hall, concert halls, a meeting hall for parishioners, Church premises, meeting rooms, and a roof garden. This solution made it possible to create a dominant position among high-rise surrounding buildings [10].

Analysis of domestic experience has shown that a common example is a compact solution of the complex. Examples of such design and implemented solutions of churches are numerous: St. Sergius of Radonezh on Khodynsky field (Moscow), The intercession of 
the Mother of God in Yasenevo (Moscow), the new Martyrs and Confessors of Domodedovo (Moscow).

Table 5. Examples of compact space-planning complexes.

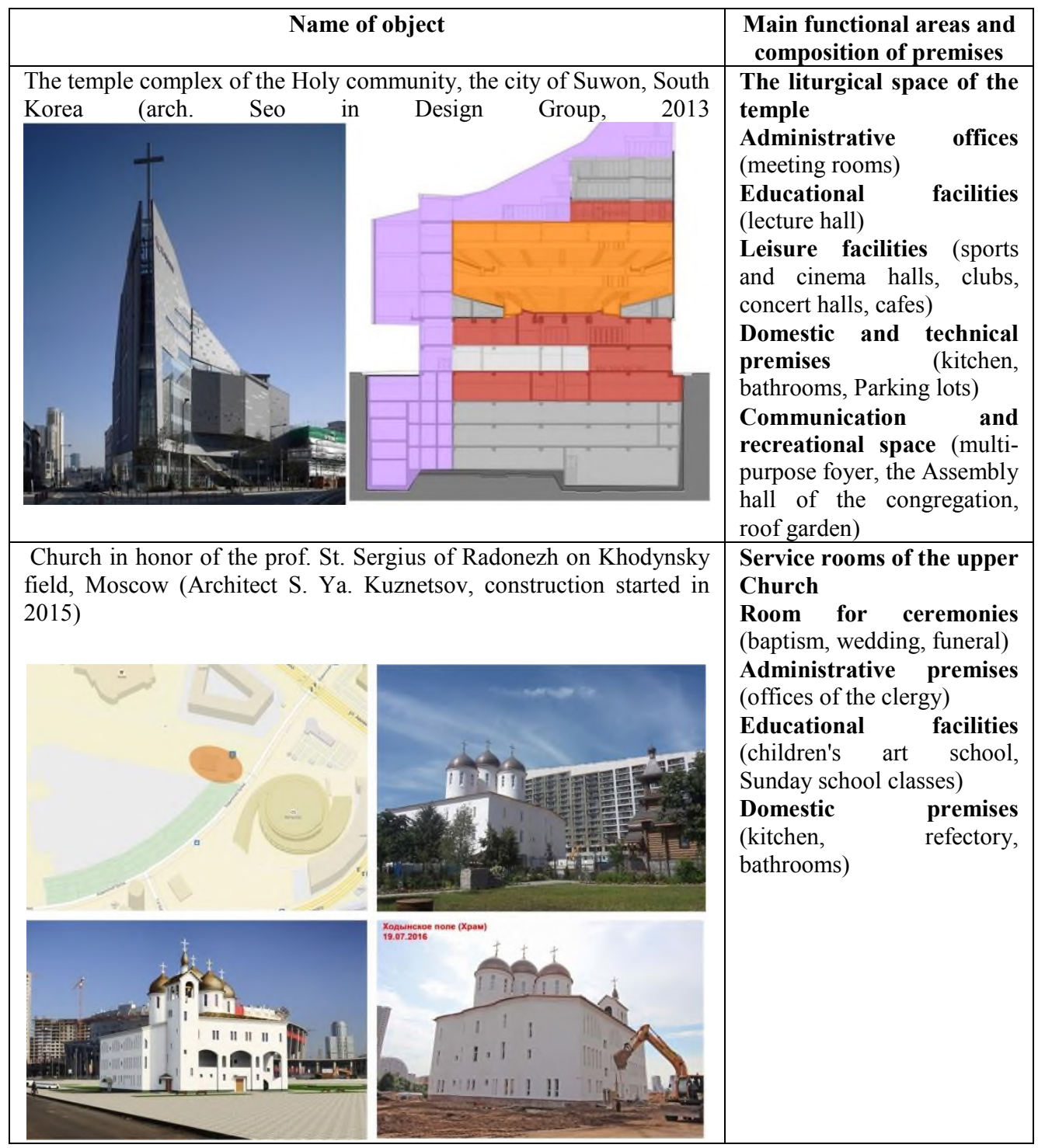

A common trend is the placement of PCC in the volume or on the territory of a complex of other functional purposes, namely, in educational institutions, residential buildings and buildings of business centers. Such solutions solve urban planning problems of placing churches in modern buildings, expand the functional composition and enrich the architectural and compositional image of complexes (table 6).

Many examples include the following: Church of Christ - hope of the world at the business center in Vienna (Austria), Church in the crowning part of a residential building in Hamburg (Germany), Church in the crowning part of a residential building in Kiev (Ukraine), Church of the presentation of the Lord on the roof of the theater "School of 
dramatic art" in Moscow, Church of St. Tatiana in Omsk state University. Dostoevsky in Omsk.

Table 6. Application of "ecological architecture" in PCC.

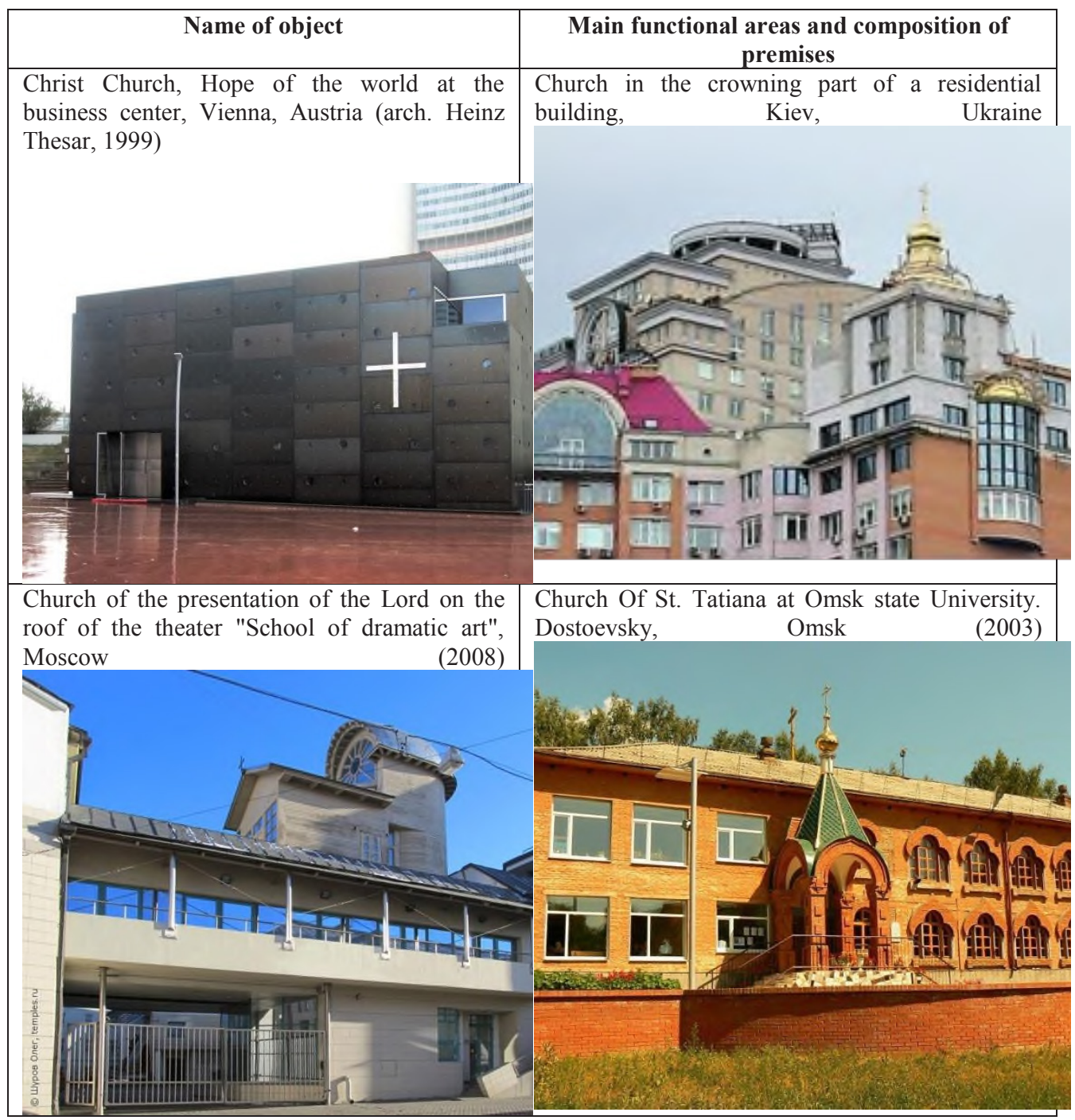

An important area is the application of "ecological architecture" in the PCC. In modern temple architecture, as well as in architectural science, the direction of "ecological architecture"is developing. In the formation of modern architecture, the means of environmental engineering and architectural and construction bionics, donated by nature itself, are used [11]. This implies modern "environmental engineering", various "green technologies" and corresponds to the religious consciousness of ideas: the harmony of forms, the organic nature of the materials used, the fusion of architecture with nature (table 7) $[12-13]$. A common technique is the introduction of a natural component into the complex (green roofs, winter garden, etc.). the "Crown" of trees on the roof of the Cathedral of the Resurrection on The Romero court in Hervey (France) creates an unusual silhouette of the building and solves the complex problem of completing the cylinder [14- 
15]. The Central interior space of the Crystal Cathedral in garden grove, California (USA) is occupied by an artificial reservoir decorated with flowers and fountains [16].

Modern experience is characterized by the use of natural and environmentally friendly materials. Examples include the Kamppi chapel of Silence in Helsinki, Finland, And the community temple in Narvik, Norway [17-18].

Table 7. Application of "ecological architecture" in PCC.

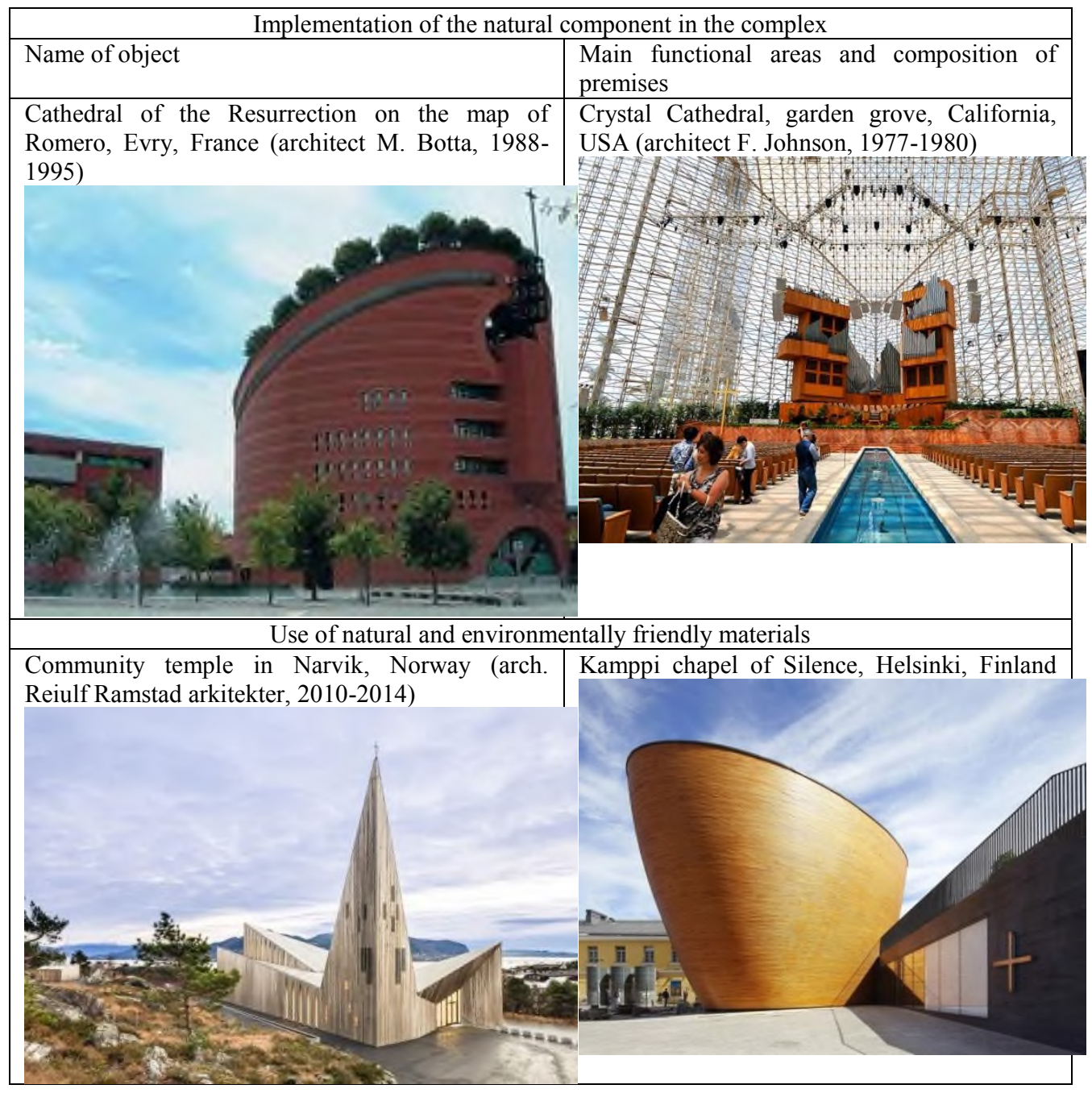

\section{Conclusions}


A comparative analysis of domestic and foreign experience allowed us to determine the features of functional planning and spatial solutions of modern PCC.

Multifunctionality and specialization is a characteristic feature of a modern parish Church. Depending on the needs of the parish and the size of the complex, PCC include various functional areas (liturgical, administrative, educational, leisure, residential, household, multifunctional communication and recreational space).

Modern PCC have a flexible functional and planning structure and can change depending on the needs and changes of the parish. The main premises of the complex are designed to be universal and subject to transformation. The space-planning structures of temple complexes can be reduced to five schemes: built-in, compact, linear, atrium and pavilion.

The image component of a modern Church is formed using innovative solutions, "green technologies", and modern design solutions.

The analysis of domestic experience allowed us to identify the problems and features of functional planning and spatial solutions.

Most PCC are monofunctional churches with a limited number of premises that are not able to effectively solve the religious and social problems facing the parish community.

Multifunctional temple complexes of various specializations are being developed: rehabilitation centers for alcohol and drug addicts, as well as centers for spiritual and moral development of young people are being formed at the temples, but these facilities are at the design or construction stage and are not widespread enough.

When choosing architectural and compositional solutions of the temple, as a rule, images of distant historical prototypes are used, which contradicts the centuries-old tradition of forming the architecture of the temple in the norms of its time.

Direct borrowing of foreign experience will not give a genuine and long-term effect, primarily due to differences in traditions.

In foreign experience, the functional content of the complex, the ways of cooperation of premises intended for conducting divine services and for organizing communication and the multilateral interests of modern people are of interest.

\section{References}

1. M.S. Ivina, Architectural typology of Orthodox parish Church complexes (on the example of Saint Petersburg) (2016)

2. Church of Santo Volto, http://www.botta.ch/page/Re\%202006_429_SantoVolto_en\%20(Sa).php\#

3. M.V. Ryaguzov, Church building in Russia. Traditions and modernity, 836-846 (1996)

4. E.V. Barantseva, Features of space-planning solutions and functional structure of spiritual and educational centers (Izvestiya vuzov, Arkhitekton, 2012) http://archvuz.ru/sites/archvuz.ru/files/pdf/ArchPHE\%2339\%28Art3\%29pp2634Barantseva.pdf

5. V.G. Temnov, G.E. Rusanov, A.L. Gelfond, S.A. Bolotin, Ecology and Architectonics Construction Objects of Urban Environmental 4(72), 95-102 (2017)

6. V.A. Zhemchugova, Church building in Russia. Tradition and modernity, 807-835 (1996)

7. M.V. Ryaguzov, Church building in Russia. Traditions and modernity, 836-846 (1996)

8. V.A. Zhemchugova, Church building in Russia. Tradition and modernity, 807-835 (1996) 
9. Church of 2000 (Richard Meier \& Partners Architects, LLP) http://www.archdaily.com/20105/church-of-2000-richard-meier

10. H. Pearman, Contemporary word architecture (Phaidon, NY, 2005)

11. V.G. Temnov, G.E. Rusanov, A.L. Gelfond, S.A. Bolotin, Ecology and Architectonics Construction Objects of Urban Environmental 4(72), 95-102 (2017)

12. V.V. Baidin, About the new image of the Russian Church (2011) http://www.russkymir.org/rm/index.php/publikatsii/khram/67-o-novom-obrazerusskogo-khrama

13. S.V. Ilvitskaya, Temple Builder 1(2), 78-80 (2013)

14. Martin Luther Church in Hainburg. Coop Himmelbau, http://www.archdaily.com/160921/martin-luther-church-in-hainburg-coop-himmelblau

15. R. Jonies, AD classics: the crystal cathedral (2014) http://www. archdaily. com/445618/ad-classics-the-crystal-cathedral-philip-johnson, consultado en junio de.

16. V.A. Zhemchugova, Church building in Russia. Tradition and modernity, 807-835 (1996)

17. C. Cennamo, C. Cusano, Architecture and Engineering 5(2), 08-16 (2020)

18. N. Kazhar, Architecture and Engineering 1(1), 19-25 (2016) 